\title{
Trust in Authorities in Regional Society: Experience of Political and Sociological Analysis
}

\author{
Zuriet Zhade ${ }^{1}{ }^{*}$ Svetlana Lyausheva ${ }^{1}$, Inna Gaidareva ${ }^{1}$, Azamat Shadzhe ${ }^{1}$ \\ ${ }^{1}$ Adyghe State University, Maykop, Russia \\ "Email: zhadezura@yandex.ru
}

\begin{abstract}
In the article, trust in the authorities is considered as a political and sociological category. The level of public confidence in the regional authorities of the Southern Federal District subjects, the Republic of Adyghe and the Krasnodar Territory, is empirically characterised. Based on the materials of a sociological study conducted by the authors in September - October 2021, citizens' degree of personal trust in authorities institutions is analysed.

In general, the population cited the inefficiency of decisions and measures taken by regional authorities as the main reason for distrust of the authorities. Among other reasons, citizens called abuse of authorities, incompetence, low level of professionalism, the closeness of the authorities, insufficient informing of the population about the situation in the region and the measures taken, low moral level of the authorities.

The data of the sociological study confirm a relatively low level of trust of citizens in regional institutions of authorities. Based on the assessments of the population, the main factors on which the level of trust in the authorities depends include: strengthening the personal responsibility of the heads of authorities; openness and transparency of the activities of authorities; taking into account public opinion when making decisions.

A comparative analysis with the results of the 2020 study conducted using identical tools shows that the level of institutional trust in the regions has decreased slightly over the year.
\end{abstract}

Keywords: Regional authorities, Trust in authorities, Institutional trust, Level of trust, Republic of Adyghe, Krasnodar Territory, Political and sociological analysis, COVID crisis.

\section{INTRODUCTION}

Trust in the authorities is a complex, complex and multidimensional phenomenon of our time. In a situation of uncertainty and risk, different types of trust can be distinguished. Thus, Yu.A. Levada defined three types: "trust as a willingness to recognise and submit to the authority of a certain person", "trust as recognition of personal virtues", "trust as recognition of the "ability" of a hero $\langle\ldots\rangle$ to take actions aimed at getting rid of some disasters" (1). Extrapolating this typology to the current circumstances of human life, we can conclude that the latter type of trust has become particularly relevant in the conditions of the COVID crisis.

Trust in the authorities largely depends on the perception of the success of the political and economic activities of public administration bodies by the population (2, p. 146). The degree of trust varies depending on the socio-political situation, "the ratio of trust in various institutions demonstrates the nonrootedness of political democracy in Russia since citizens systematically trust the institutions of the "vertical of authorities" more strongly, but much weaker - connected with political competition" (3, p. 161).

The following circumstances of the political agenda testify to the degree of urgency of the designated problem. Firstly, the creation of conditions for trusting relations between the state and society is enshrined as a constitutional priority in the Constitution of the Russian Federation updated in 2020. Secondly, a new vector of discussion on the assessment of institutional trust is set by the Decree of the President of the Russian Federation No. 68 dated February 4, 2021 "On evaluating the effectiveness of the activities of senior officials (heads 
of the Highest Executive bodies of State Authorities) of the Subjects of the Russian Federation and the activities of executive authorities of the Subjects of the Russian Federation", in which trust is designated as the main criterion for the effectiveness of authorities.

A long-term study of (non)trust shows the complex nature of this phenomenon. "The categorical dialectical pair "trust/distrust" is an extremely complex, complex concept with a very high substantive scientific potential, for which, at least at the time, theoretical understanding is still quite limited" (4, pp. 60-61). Traditionally, political trust is considered as "the confidence of the citizens of a country (or some part of them) in the correctness of the political positions and actions of certain political forces, institutions, state and political figures, the conformity of their political positions to their own beliefs, in the ability of specific political actors to realise the declared goals and program settings, readiness to support them" $(5$, p. 81).

Currently, research interest in the phenomenon of trust has significantly increased - the subject of study of various branches of the world socio-humanitarian science, within which it is necessary to identify the main approaches to the study of trust: the conceptualisation of trust in the theory of risk, trust as an element of social capital and trust in the cultural aspect. The conceptual framework of this study is determined by the ideas of E. Giddens (6), N. Luhmann (7), F. Fukuyama (8) and P. Shtompki (9), who interpret trust from different methodological positions.

Many works are devoted to discussions about the essence and assessment of trust in authorities. Trust is most often considered in the following contexts: institutional trust/distrust $(4 ; 10 ; 11)$; political trust $(12$; 13); trust as social capital and resource (3); trust in the context of self-authorities and public participation (2; $14)$; digital trust (15); trust in the system of basic values (16). At the same time, the mechanisms and technologies for increasing confidence in the authorities in crises remain practically unexplored.

Leaving this scientific discussion out of the brackets of our analysis, we associate ourselves with the point of view that "trust is a unique phenomenon of public life, the demand for which increases in the conditions of the deployment of transformational processes. It primarily ensures stability and determines the prospects for the sustainable development of any society. <...> It contributes to the formation of stable and reliable social ties that strengthen society, promote the development of integration processes and the smoothing of socioeconomic barriers within society" (17, pp. 134-135). In our study, trust in the authorities is considered as a political and sociological category.

\section{RESEARCH METHODOLOGY}

The methodological basis of the study consisted of an interdisciplinary approach to measuring trust in authorities; the principle of consistency allowed us to consider the interaction of authorities and society in the context of structural and functional changes in this system; the survey method allowed us to measure the level of trust in authorities and assess the impact of the pandemic, to develop mechanisms for strengthening trust in authorities, taking into account regional specifics; the method of analysing secondary sociological information allowed us to correlate the data obtained during empirical research; the comparative method allowed us to compare the level of trust in authorities in two regions, as well as to analyse the peculiarities of the manifestation of trust in authorities in the studied regions, based on differences in their political and legal status (national republic and territory).

\section{THE EMPIRICAL BASE OF THE STUDY}

To determine the degree of public confidence in regional authorities during the "fourth wave" of COVID, the research team of Adyghe State University conducted a sociological survey in the Republic of Adyghe (RA) and Krasnodar Territory (KT) in September-October 2021. The primary tool is a standardised questionnaire suitable for personal questioning and used in Google Forms with anonymous filling in by respondents. The survey was conducted on a quota-proportional sample. The main questions of the questionnaire are presented for the purpose of comparative analysis with the results of a previous similar study (18). The empirical abjects are the population of four municipalities of the Republic and the Territory (the city of Maykop, Krasnogvardeysky, Takhtamukaysky and Teuchezhsky districts) ( $\mathrm{n}=508)$ and (Krasnodar city, Belorechensky, Kurganinsky and Labinsky districts) ( $\mathrm{n}=583)$.

\section{STUDY RESULTS}

At the centre of our research were the following questions: What is happening with trust in the regions of Russia in the era of the corona crisis? What is the level of trust in the authorities? One of the main indicators of trust in authorities structures is citizens' degree of personal trust. The starting point of the analysis is the results of the study, which are based on the respondents' answers to the question "Do you trust the following bodies, structures, institutions in the context of a pandemic?». The research data show that 27.1 and $20 \%$ of respondents fully trust the head of the republic and the governor of the region, rather trust (32 and 27.9\%), rather do not trust (12.4 and 19.3\%), do not trust (7.4 and $15 \%)$, found it difficult to answer (20.8 and $17.4 \%)$ (Table 1). 
Table 1. Distribution of answers to the question: "Do you trust the following bodies, structures, institutions in the context of a pandemic?" (one answer option, in \%)

\begin{tabular}{|c|c|c|c|c|c|c|c|c|c|c|}
\hline \multirow[t]{2}{*}{ Response options } & \multicolumn{2}{|c|}{$\begin{array}{l}\text { completely } \\
\text { trust }\end{array}$} & \multicolumn{2}{|c|}{ rather trust } & \multicolumn{2}{|c|}{$\begin{array}{l}\text { Rather don't } \\
\text { trust }\end{array}$} & \multicolumn{2}{|c|}{ Don't trust } & \multicolumn{2}{|c|}{$\begin{array}{l}\text { It difficult to } \\
\text { answer }\end{array}$} \\
\hline & RA & KT & RA & KT & RA & $\mathrm{KT}$ & RA & KT & RA & KT \\
\hline $\begin{array}{l}\text { To the President of the } \\
\text { Russian Federation }\end{array}$ & 25.9 & 29.1 & 27.9 & 25.3 & 16 & 13.8 & 9.6 & 13.3 & 20.8 & 18.1 \\
\hline $\begin{array}{l}\text { To the Head of the } \\
\text { region }\end{array}$ & 27.1 & 20 & 32 & 27.9 & 12.4 & 19.3 & 7.4 & 15 & 20.8 & 17.4 \\
\hline $\begin{array}{l}\text { To the Executive } \\
\text { authorities of the } \\
\text { region }\end{array}$ & 20.4 & 19 & 27.6 & 27 & 18.3 & 20 & 8.6 & 15 & 20.8 & 17.6 \\
\hline $\begin{array}{l}\text { To the legislative } \\
\text { authorities of the } \\
\text { region }\end{array}$ & 19.4 & 18.5 & 27.6 & 27.6 & 18.7 & 20 & 8.8 & 15 & 21.2 & 17.4 \\
\hline $\begin{array}{l}\text { To the City/Village } \\
\text { Administration }\end{array}$ & 19 & 19 & 33 & 28.3 & 17.7 & 19.3 & 8.4 & 15.6 & 21.6 & 17.6 \\
\hline $\begin{array}{l}\text { To the Law } \\
\text { enforcement } \\
\text { authorities }\end{array}$ & 21 & 19.3 & 33.2 & 28.8 & 15.7 & 20.4 & 8.8 & 14.5 & 21 & 16.8 \\
\hline $\begin{array}{l}\text { To the Healthcare } \\
\text { organisations }\end{array}$ & 20.4 & 19.2 & 33 & 32 & 16.1 & 17.8 & 10.6 & 14.9 & 19.6 & 15.9 \\
\hline $\begin{array}{l}\text { To the Public } \\
\text { organisations }\end{array}$ & 18.3 & 17.8 & 34.2 & 33.1 & 16.5 & 17.1 & 8.8 & 13.5 & 22 & 18.3 \\
\hline To the Media & 15.3 & 16.1 & 31.1 & 27.7 & 21 & 18.3 & 11 & 19.8 & 21.4 & 17.8 \\
\hline
\end{tabular}

The level of trust of citizens towards the President of the Russian Federation in both regions is almost similar: 27.1 and $29.1 \%$ - fully trust; 27.9 and $25.3 \%$ - rather trust; 16 and $13.8 \%$ - rather do not trust. And only 9.6 and $13.3 \%$ do not trust (Table 1). It seems that these data are evidence that the head of the country, in the eyes of citizens, is a symbol of stability and order in the country. The data obtained by us generally correlate with the results of the trust rating of politicians conducted in November 2021. by the ARPORC: $64.4 \%$ of respondents trust the President of the Russian Federation (19).

It should be emphasised that "in the conditions of the COVID-19 pandemic, those who trusted the president more often followed the calls from the authorities for health-saving behaviour and were about $19 \%$ less likely to get sick" (3, p. 172).

According to the results obtained, among the institutions of authority, law enforcement agencies enjoy the most significant trust among the population
(21 and 19.3\%), executive (20.4 and 19\%) and legislative authorities (19.4 and 18.5\%) aroused slightly less trust among respondents. City/village administrations were assessed at the same level (19\%) in two regions. To the least extent, the population trusts public organisations (18.3 and 17.8\%), then the mass media (15.3 and $16.1 \%$ ) (Table 1).

As part of the study, an attempt was made to find out the main reasons for the distrust of the authorities. In general, the population's inefficiency of decisions and measures taken by regional authorities was named the main reason for distrust of the authorities (24.6 and $25.6 \%)$. Among other reasons, citizens named abuse of authorities (22 and 23\%), and 20.7 and $16.1 \%$ of respondents see the reason in incompetence, low level of professionalism of the relevant authorities in the case of citizens' appeals to solve any problem. 19.1 and $21.8 \%$ cite the closeness of the authorities, insufficient informing of the population about the situation in the 
Table 2. Distribution of answers to the question: "What could be the main reasons for distrust of the authorities?" (multiple answer options, in \%)

\begin{tabular}{|c|c|c|}
\hline Response options & RA & $\mathrm{KT}$ \\
\hline the inefficiency of decisions and measures taken & 24.6 & 25.6 \\
\hline abuse of authorities & 22 & 23 \\
\hline $\begin{array}{l}\text { incompetence, low level of professionalism of the relevant authorities in the case of } \\
\text { citizens' appeals to solve any problem }\end{array}$ & 20.7 & 16.1 \\
\hline $\begin{array}{l}\text { the closeness of the authorities, insufficient informing of the population about the } \\
\text { situation in the region and the measures taken }\end{array}$ & 19.1 & 21.8 \\
\hline the low moral level of authorities & 9.4 & 9.8 \\
\hline
\end{tabular}

region and the measures taken; 9.4 and $9.8 \%$ indicated a low moral level of the authorities (Table 2).

Trust in the authorities is determined mainly by the degree of its openness to society. This confirms the distribution of answers to the question about measures to increase confidence in the authorities. In both groups, the overwhelming majority chose the option "openness and transparency of authorities activities" (44.7 and $44.4 \%)$. The shares of those who indicated the option "strengthening the personal responsibility of the heads of authorities" also practically do not differ (39.8 and $37.4 \%$ ). One of the mechanisms for increasing trust in authorities representatives is considering public opinion. This option was chosen by 38.4 and $41.5 \%$ of respondents. (Table 3 ).

Trust to the authorities directly relates to fundamental and situational ideas about authorities, which are reflected in knowledge and statements about it and the corresponding values and orientations. Individuals tend to correlate the actions carried out by public authorities with their values and expectations. On this basis, identification with the authorities can be formed as "one's own", "close", or, on the contrary, "alien" and "hostile". In other words, the prerequisite for forming a high level of trust in the authorities is the correspondence of the value orientations of citizens and their expectations from the authorities and its real activities, the content of the state policy.

Within the research framework, we were interested in the respondents' point of view regarding the main components of trust in the authorities. According to the respondents, great importance for increasing confidence

Table 3. Distribution of answers to the question: "What measures can influence the increase of confidence in the authorities?" (multiple answer options, in \%)

\begin{tabular}{|l|c|c|}
\hline \multicolumn{1}{|c|}{ Response options } & RA & KT \\
\hline strengthening the personal responsibility of the heads of authorities & 39.8 & 37.4 \\
\hline openness and transparency of the activities of the authorities & 44.7 & 44.4 \\
\hline considering public opinion when making decisions & 38.4 & 41.5 \\
\hline equal dialogue between the authorities and society & 30.9 & 35 \\
\hline the possibility of real participation of citizens in the management process & 19.7 & 24 \\
\hline the decisions made must be fair & 31.3 & 29.7 \\
\hline strengthening public control & 13 & 15.6 \\
\hline improving the quality of public services & 28.1 & 29 \\
\hline solving the problems of specific people "at the local level" & 17.9 & 24.5 \\
\hline It difficult to answer & 10.8 & 8.4 \\
\hline
\end{tabular}


Table 4. Distribution of answers to the question: "What is the basis of trust in the authorities?» (one answer option, in \%)

\begin{tabular}{|c|c|c|c|c|}
\hline \multirow[t]{2}{*}{ Response options } & \multicolumn{2}{|c|}{$\begin{array}{l}\text { it doesn't matter at } \\
\qquad \text { all }\end{array}$} & \multicolumn{2}{|c|}{$\begin{array}{l}\text { is of great } \\
\text { importance }\end{array}$} \\
\hline & RA & KT & RA & KT \\
\hline support of actions and measures implemented by the authorities & 13.6 & 14.4 & 23 & 23.3 \\
\hline agreement with the authorities' policy & 13.2 & 15.1 & 19.7 & 20.1 \\
\hline the fairness of decisions made by the authorities & 13.6 & 13.9 & 32.7 & 34.5 \\
\hline the habit of trusting the authorities, traditions & 17.3 & 25.4 & 20.3 & 12.5 \\
\hline $\begin{array}{l}\text { confidence in the proper performance of their functions by the } \\
\text { authorities }\end{array}$ & 13.6 & 14.5 & 28.5 & 30 \\
\hline faith in the honesty and decency of the authorities & 15.1 & 17 & 28.7 & 30.5 \\
\hline active support of the authorities & 15.7 & 17.8 & 24.4 & 19.2 \\
\hline
\end{tabular}

in the authorities is, first of all, faith in the honesty and decency of the authorities (28.7 and 30.5\%); secondly, confidence in the proper performance of their functions by the authorities (28.5 and $30 \%$ ); thirdly, active support of the authorities (24.4 and 19.2\%). The surveyed citizens believe that in this process, the habit of trusting the authorities and traditions does not matter at all (17.3 and 25.4\%) (Tab. 4).

In our opinion, the measures envisaged to increase the level of trust in the authorities, first of all, should include providing citizens with the opportunity to influence the process of making managerial decisions. Respondents from both regions, answering the question about the ability of citizens to influence the decisions of the authorities, are more likely to believe that they practically do not have (35.2 and 41.7\%). The answer "in some cases" was chosen by 30.5 and $28.5 \%$. Only 13.2 and $12.9 \%$ are convinced that citizens can influence management decisions. And in this matter, the opinion of the surveyed population of the regions in question generally coincides.

\section{CONCLUSIONS}

The analysis of the level of trust, the reasons for distrust, the components of trust, measures to increase confidence in the authorities, based on the results of applied research, allows us to conclude that the population of the two designated regions as a whole expresses their positions similarly. The main reason for this, in our opinion, is that the Republic and the Territory have the same historical, cultural, territorial and geographical characteristics, also have the same status as a subject of the federation and belong to the Southern Federal District.
The data of the sociological study confirm a relatively low level of trust of citizens in regional institutions of authorities. Based on the assessments of the population of the Republic of Adyghe and the Krasnodar Territory, the main factors on which the level of trust in the authorities depends include: firstly, strengthening the personal responsibility of the heads of authorities; secondly, openness and transparency of the activities of authorities; thirdly, taking into account public opinion when making decisions.

A comparative analysis of the materials of a modern survey with the results of last year's study shows that the level of institutional trust in the regions has decreased slightly over the year.

The results of the study can be used to calculate the index of trust in authorities and analyse its main components and characteristics at the regional level; identify information and communication, organisational, legal and other technologies to increase public confidence in authorities, including in social media; identify effective mechanisms to strengthen institutional trust; identify ways to improve the effectiveness of management technologies to strengthen public confidence in regional authorities.

\section{ACKNOWLEDGMENTS}

The reported study was funded by RFBR and EISR, project number 21-011-31778.

\section{REFERENCES}

[1] Yu.A. Levada, From opinions to understanding. Sociological essays [Ot mnenij k ponimaniyu. Sociologicheskie ocherki] 1993-2000, Moscow: MSPI, 2000, $574 \mathrm{p}$. 
[2] T.N. Litvinova, The effectiveness of regional authorities: from theory to measurement (on the example of the Republics of the North Caucasus Federal District) [Effektivnost' regional'noj vlasti: ot teorii $\mathrm{k}$ izmereniyu (na primere respublik Severo-Kavkazskogo federal'nogo okruga)], Political Studies [Politicheskie issledovaniya], 29(2) (2020) 137-152. DOI: https://doi.org/10.17976/jpps/2020.02.10

[3] Yu.V. Latov, Institutional trust as social capital in modern Russia (based on monitoring results) [Institucional'noe doverie kak social'nyj kapital v sovremennoj Rossii (po rezul'tatam monitoringa)], Political Studies [Politicheskie issledovaniya] 5 (2021) 161-175. DOI: https://doi.org/10.17976/jpps/2021.05.11

[4] M. Sasaki, V.A. Davydenko, G.F. Romashkina, V.V. Voronov, Comparative analysis of trust in different countries [Sravnitel'nyj analiz doveriya v razlichnyh stranah]. Sociological Research [Sociologicheskie issledovaniya] 3 (2013) 60-73.

[5] P.M. Kozyreva, A.I. Smirnov, Political Trust in Russia: some features and the optimality problem [Politicheskoe doverie v Rossii: nekotorye osobennosti i problema optimal'nosti]. Bulletin of the Institute of Sociology [Vestnik Instituta sociologii] 12 (2015) 79-99.

[6] E. Giddens, The Consequences of modernity. Translated from English by G.K. Olkhovikov; D.A. Kibalchich; intro. article by T.A. Dmitriev. Moscow: Praxis, 2011, 352 p.

[7] N. Luhmann, Introduction to System Theory (edited by D. Becker). Translated from German / K. Timofeeva. Moscow: Logos, 2007, 360 p.

[8] F. Fukuyama, Trust: Social Virtues and the Path to Prosperity. Moscow: AST; NPP "Ermak", 2004, $730 \mathrm{p}$.

[9] P. Shtompka, Trust is the basis of society / transl. from the pol. by N.V. Morozova. Moscow: Logos, 2012, 445 p.

[10] Trust and distrust in the conditions of civil society development [Doverie i nedoverie v usloviyah razvitiya grazhdanskogo obshchestva] / ed. by A.B. Kupreichenko, I.V. Mersiyanova. Moscow: Publishing House of the Higher School of Economics, 2013, 564 p.

[11] I.N. Trofimova, Structure and dynamics of institutional trust in modern Russian society [Struktura i dinamika institucional'nogo doveriya $\mathrm{v}$ sovremennom rossijskom obshchestve], Sociological research [Sociologicheskie issledovaniya] 5 (2017) 68-75.
[12] G.A. Satarov, Trust as an object of political sociology. Part I [Doverie kak ob"ekt politicheskoj sociologii. Chast' I], Political Studies [Politicheskie issledovaniya] 1 (2016) 121-138. DOI: https://doi.org/10.17976/jpps/2016.01.09

[13] D.F. Terin, Political trust, satisfaction and perceptions of the causes of poverty: the role of normative aspects of institutions in the production of trust [Politicheskoe doverie, udovletvorennost' i predstavleniya o prichinah bednosti: rol normativnyh aspektov institutov $\mathrm{v}$ proizvodstve doveriya], Political Studies [Politicheskie issledovaniya] 3 (2020) 144-157. DOI: https://doi.org/10.17976/jpps/2020.03.10

[14] R.V. Petukhov, Russian society's trust in local selfgovernment bodies as a problem [Doverie rossijskogo obshchestva $\mathrm{k}$ organam mestnogo samoupravleniya kak problema], Political Studies [Politicheskie issledovaniya] 6 (2017) 61-75. DOI: https://doi.org/10.17976/jpps/2017.06.05

[15] Yu.V. Veselov, N.G. Skvortsov, Trust in the era of digital transformations: the experience of sociological research [Doverie v epohu cifrovyh transformacij: opyt sociologicheskogo issledovaniya], Sociological Research [Sociologicheskie issledovaniya] 6 (2021) 57-68. DOI:

https://doi.org/10.31857/S013216250012556-4

[16] L.E. Ilyicheva, A.V. Lapin, P. Kremer, Trust in the system of basic values of Russia and Germany: consequences of the pandemic, Problems of National Strategy [Doverie v sisteme bazovyh cennostej Rossii i Germanii: posledstviya pandemii, Problemy nacional'noj strategii] 64(1) (2021) 97-118

[17] P.M. Kozyreva, A.I. Smirnov, Trust in an unstable Russian Society [Doverie v nestabil'nom rossijskom obshchestve], Political Studies [Politicheskie issledovaniya] 5 (2019) 134-147. DOI: https://doi.org/10.17976/jpps/2019.05.10

[18] Z. Zhade, A. Shadzhe, S. Lyausheva, N. Ilinova, E. Kukva, 2021. Regional authorities and society in the context of the COVID-19 pandemic: indicators of integration. Proceedings of the VIII International Scientific and Practical Conference "Current problems of social and labour relations" (ISPC-CPSLR 2020), Advances in Social Science, Education and Humanities Research, Vol. 527, pp. 736-741.

DOI:

https://doi.org/10.2991/assehr.k.210322.208

[19] Trust in politicians [Doverie politikam]. Retrieved from: https://wciom.ru/ratings/doverie-politikam/ 